\title{
POST-TRAUMATIC SYRINGOMYELIA
}

\author{
By J. D. Vernon, M.B., B.Chir., ${ }^{1}$ J. R. Silver, M.B., B.S., F.R.C.P. (Ed. \\ \& London), and A. OHRY, M.D. ${ }^{2}$ \\ ${ }^{1}$ National Spinal Injuries Centre, Stoke Mandeville Hospital, Aylesbury, Bucks., \\ HP2I 8AL. '2 Spinal Injuries Centre, The Chaim Sheba Medical Centre, Tel- \\ Hashomer, Israel.
}

\begin{abstract}
A description is given of the syndrome of post-traumatic syringomyelia amongst patients with traumatic spinal injuries seen at the National Spinal Injuries Centre. The diagnosis was made on clinical grounds. It was confirmed wherever possible by neuroradiology prior to surgery; one case was confirmed only at postmortem. The incidence of the condition was found to be in keeping with other large series but, in contrast, no difference was found between the time of onset after injury between complete and incomplete lesions of the spinal cord. The commonest manifestation was pain, followed by sensory loss and rarely motor weakness. In the majority of patients the condition eventually became bilateral and in a significant number the lesion ascended to involve the trigeminal territory. The natural history of the condition was followed, and in all cases the condition gradually progressed. The pathogenesis of the condition is briefly discussed in view of the findings.
\end{abstract}

Key words: Post-Traumatic Syringomyelia; Clinical Features; Natural History.

\section{Introduction}

SYRINGOMYELIA as a late sequel to traumatic paraplegia and tetraplegia has been described by Bastian (I876), Strumpell (I880), Holmes (I9I5), Freeman (1959), Finckle (1960), Barnett, Bottrell, Jousse and Wynn-Jones (1966), Gardner (1973), Barnett, Foster and Hudgson (1973), Shannon, Symon, Logue, Cull, Kang and Kendall (I98I). Barnett et al. (I966) found a clinical picture suggesting syrinx formation in Io patients out of a total of 59I paraplegic patients admitted to Lyndhurst Lodge between 1945 and I 966 but were only able to confirm this at operation in one patient. In their monograph of I 973 Barnett, Foster and Hudgson outlined the clinical features of this condition in 17 out of a total of 1,387 patients admitted between 1945 and 1971 and reviewed the findings in a further 56 patients from other sources. This is a rare condition. However, in view of the relatively large number of cases that we have seen at the National Spinal Injuries Centre, Stoke Mandeville Hospital, we are presenting the features of this complication in a further 40 patients.

\section{Clinical Material}

Some 6,800 patients have been seen at the National Spinal Injuries Centre since it was opened in 1944 but not all patients had traumatic injuries. Many patients have only been seen on one occasion, some have died, some have been referred to other centres and some have returned overseas. Other patients have been unwilling to return for check ups. We are presenting 
TABLE I

\begin{tabular}{|c|c|c|c|c|c|c|}
\hline Name & $\begin{array}{l}\text { Age at } \\
\text { Injury }\end{array}$ & Level & $\begin{array}{l}\text { Interval to } \\
\text { New Symptoms }\end{array}$ & New Symptoms & $\begin{array}{l}\text { New Motor or } \\
\text { Sensory Signs }\end{array}$ & $\begin{array}{l}\text { Duration of } \\
\text { Follow up } \\
\text { After Injury } \\
\text { (years) }\end{array}$ \\
\hline R.P. & 46 & $\begin{array}{l}\text { Incomplete } \\
\text { L4 } \\
\text { Complete S I }\end{array}$ & I3 years & $\begin{array}{l}\text { Bilateral girdle pain, mainly } \\
\text { right. }\end{array}$ & $\begin{array}{l}\text { Right sided dissociate sensory } \\
\text { loss, D5-D8. }\end{array}$ & 17 \\
\hline R.S. & 20 & $\begin{array}{l}\text { Incomplete } \\
\text { C7 } \\
\text { Complete } \\
\mathrm{D}_{3}\end{array}$ & 20 years & $\begin{array}{l}\text { Pain in the left shoulder. } \\
\text { Bilateral loss of pain } \\
\text { sensation in neck. }\end{array}$ & $\begin{array}{l}\text { Bilateral dissociate sensory loss } \\
\mathrm{CI}_{\mathrm{I}}-\mathrm{D}_{3} \text {. Sweating right side of } \\
\text { body. }\end{array}$ & 26 \\
\hline G.B. & I 5 & $\begin{array}{l}\text { Complete } \\
\text { D i I }\end{array}$ & I9 years & $\begin{array}{l}\text { Pain in neck, both shoulders } \\
\text { and upper limbs. Loss of } \\
\text { pain sensation both hands. }\end{array}$ & $\begin{array}{l}\text { Fluctuating sensory loss of } \\
\text { trigeminal, sparing C. } 3 \text {, then } \\
\text { C5-D I. Pain in first left } \\
\text { metacarpophalangeal joints } \\
\text { (osteoarthritis). Migraine, } \\
\text { dizziness. Ulna sensory changes } \\
\text { right and left. (Generalised } \\
\text { bilateral weakness). }\end{array}$ & 26 \\
\hline M.M. & $3 I$ & $\begin{array}{l}\text { Complete } \\
\text { D8 }\end{array}$ & I 5 years & $\begin{array}{l}\text { Girdle pain at level of lesion. } \\
\text { Loss of pain sensation trunk } \\
\text { and numbness right upper } \\
\text { limb. }\end{array}$ & $\begin{array}{l}\text { Dissociate sensory loss } \mathrm{D}_{3}-\mathrm{D} 8 \\
\text { (preservation tendon reflexes). }\end{array}$ & I 6 \\
\hline B.H. & 26 & $\begin{array}{l}\text { Incomplete } \\
\text { C8 }\end{array}$ & I3 years & $\begin{array}{l}\text { Pain in both arms, left face, } \\
\text { progressive weakness in lower } \\
\text { limbs. }\end{array}$ & $\begin{array}{l}\text { Dejerine left face, dissociate loss } \\
\text { down to } D_{7} \text {. General weakness } \\
\text { in all } 4 \text { limbs. }\end{array}$ & $2 \mathrm{I}$ \\
\hline P.M. & 22 & $\begin{array}{l}\text { Complete } \\
\mathrm{D}_{4}\end{array}$ & 8 years & $\begin{array}{l}\text { Painful spasms right upper } \\
\text { limb followed by loss of pain } \\
\text { sensation. }\end{array}$ & $\begin{array}{l}\text { Right dissociate sensory loss } \\
\mathrm{C}_{3}-\mathrm{D} 4 \text { and weakness of right } \\
\text { hand. Involvement of right } \\
\text { trigeminal distribution } \\
\text { (migraine). }\end{array}$ & 22 \\
\hline
\end{tabular}




\begin{tabular}{|c|c|c|c|c|}
\hline T.G. & $2 \mathrm{I}$ & $\begin{array}{l}\text { Complete } \\
\text { D7 }\end{array}$ & $\begin{array}{l}\text { Less than a } \\
\quad \text { year }\end{array}$ & $\begin{array}{l}\text { Sudden onset loss of feeling } \\
\text { right upper limb. }\end{array}$ \\
\hline W.W. & 23 & $\begin{array}{l}\text { Complete } \\
\text { D7 }\end{array}$ & 7 years & $\begin{array}{l}\text { Pain at } \mathrm{D}_{7} \text { radiating to left } \\
\text { shoulder and arm. }\end{array}$ \\
\hline J.M. & I 8 & $\begin{array}{l}\text { Incomplete } \\
\text { C6 }\end{array}$ & 3 years & $\begin{array}{l}\text { Pain left upper limb and } \\
\text { left chest }+ \text { spinothalamic loss } \\
\text { No sweating in these parts. }\end{array}$ \\
\hline J.D. & I 8 & $\begin{array}{l}\text { Incomplete } \\
\text { D5 }\end{array}$ & I I years & $\begin{array}{l}\text { Pain in neck radiating to left } \\
\text { arm. Sweating, weakness left } \\
\text { arm. }\end{array}$ \\
\hline K.T. & 33 & $\begin{array}{l}\text { Complete } \\
\text { D7 }\end{array}$ & 2 years & $\begin{array}{l}\text { Loss of sensation of pain } \\
\text { left trunk and left arm. }\end{array}$ \\
\hline J.R. & 20 & $\begin{array}{l}\text { Complete } \\
\text { D7 }\end{array}$ & I year & $\begin{array}{l}\text { Chest pain. Weakness with } \\
\text { loss of temperature sensation } \\
\text { left upper limb. }\end{array}$ \\
\hline K.A. & 59 & $\begin{array}{l}\text { Incomplete } \\
\text { C6 }\end{array}$ & 8 years & $\begin{array}{l}\text { Pain left neck, shoulder. } \\
\text { Increasing weakness left hand }\end{array}$ \\
\hline D.R. & 24 & $\begin{array}{l}\text { Incomplete } \\
\text { Di2 }\end{array}$ & I 8 years & $\begin{array}{l}\text { Swelling right forearm, loss } \\
\text { of feeling right upper limb } \\
\text { with weakness right hand. }\end{array}$ \\
\hline
\end{tabular}

Right dissociate sensory loss

$\mathrm{C}_{7}-\mathrm{T}_{2}$ with minimal weakness

right hand.

Dissociate sensory loss left trigeminal, left upper limb $\left(\mathrm{C}_{3}\right.$

-D4 with weakness of left upper limb. Severe head pain on stooping.

Dissociate sensory loss $\mathrm{C}_{2}-\mathrm{D}_{3}$

left. Weak extensor of left elbow. Anhydrosis $\mathrm{C}_{2}-\mathrm{D}_{3}$ left. Dissociate sensory loss below $\mathrm{C}_{5}$ on the right.

Weakness left arm. Left trigeminal involvement.

Dissociate sensory loss $\mathrm{C}_{3}-\mathrm{D}_{5}$.

Dissociate sensory loss $\mathrm{C}_{3}-\mathrm{D} 6$.

Weakness of left finger flexion and intrinsic muscles.

Dissociate sensory loss $\mathrm{C}_{2}-\mathrm{D}_{1}$.

Dissociate loss left $\mathrm{C}_{2}-\mathrm{C} 8$,

wasted triceps and hand intrinsics.

4

Impairment of all modalities of sensation right arm $\mathrm{C}_{4}-\mathrm{D}_{3}$. Feels normally until Dio. 
TABLE I continued

\begin{tabular}{|c|c|c|c|c|c|c|}
\hline Name & $\begin{array}{l}\text { Age at } \\
\text { Injury }\end{array}$ & Level & $\begin{array}{l}\text { Interval to } \\
\text { New Symptoms }\end{array}$ & New Symptoms & $\begin{array}{l}\text { New Motor or } \\
\text { Sensory Signs }\end{array}$ & $\begin{array}{l}\text { Duration of } \\
\text { Follow up } \\
\text { After Injury } \\
\quad \text { (years) }\end{array}$ \\
\hline D.K. & 29 & $\begin{array}{l}\text { Incomplete } \\
\text { D I2 }\end{array}$ & I5 years & $\begin{array}{l}\text { Swelling of right arm. } \\
\text { Paraesthesia, sensory loss, } \\
\text { progressive weakness right } \\
\text { upper limb followed by } \\
\text { similar changes on left. } \\
\text { Increasing weakness left leg. }\end{array}$ & $\begin{array}{l}\text { Dissociate sensory loss } \mathrm{C}_{2}-\mathrm{C} 8 \\
\text { on the right, similar changes on } \\
\text { the left. Charcot shoulder on } \\
\text { the right. }\end{array}$ & 23 \\
\hline T.M. & 26 & $\begin{array}{l}\text { Incomplete } \\
\text { D9 }\end{array}$ & 2 months & $\begin{array}{l}\text { Tingling numbness, weakness } \\
\text { right hand. }\end{array}$ & $\begin{array}{l}\text { Sensory impairment right ulna } \\
\text { distribution with weakness, then } \\
\text { I } 4 \text { months later sudden loss } \\
\text { of } C_{7}, 8 \text {, T I sensation } \\
\text { precipitated by coughing. } \\
\text { Depressed right triceps jerk. }\end{array}$ & 2 \\
\hline S.K. & 8 & $\begin{array}{l}\text { Incomplete } \\
\text { C6 }\end{array}$ & I 5 years & $\begin{array}{l}\text { Pain in left shoulder with } \\
\text { weakness and impairment of } \\
\text { sensation to involve the whole } \\
\text { of left upper limb and face } \\
\text { + weakness of right hand. }\end{array}$ & $\begin{array}{l}\text { Bilateral sensory impairment } \\
\text { incomplete below } \mathrm{C}_{2} \text { on the left, } \\
\mathrm{C}_{4} \text { on right with trigeminal } \\
\text { involvement on left. }\end{array}$ & I 7 \\
\hline D.Ho. & $2 \mathrm{I}$ & $\begin{array}{l}\text { Incomplete } \\
\text { L3 }_{3}\end{array}$ & 23 years & $\begin{array}{l}\text { Partial loss of pain sensation } \\
\text { in right upper limb, denser } \\
\text { loss in left hand of sensory } \\
\text { modalities. }\end{array}$ & $\begin{array}{l}\text { Dissociate sensory loss } \mathrm{C}_{5}-\mathrm{L}_{3} \\
\text { on right followed by dense } \\
\mathrm{C}_{7}-\mathrm{D}_{3} \text { on left. }\end{array}$ & 25 \\
\hline S.W. & I 8 & $\begin{array}{l}\text { Incomplete } \\
\text { D8 }\end{array}$ & I7 years & $\begin{array}{l}\text { Back pain. Loss of feeling } \\
\text { in left upper limb. }\end{array}$ & $\begin{array}{l}\text { Dissociate sensory loss } \mathrm{CI}_{\mathrm{I}}-\mathrm{D}_{4} \\
\text { on left, then complete loss } \\
\text { D8-Li both sides with global } \\
\text { weakness of left hand. }\end{array}$ & $3 I$ \\
\hline
\end{tabular}




\begin{tabular}{|c|c|c|c|c|c|}
\hline G.V. & 39 & $\begin{array}{l}\text { Complete } \\
\text { D } 12\end{array}$ & 2 years & Pain in neck and shoulders. & $\begin{array}{l}\text { Dissociate sensory loss C5-Di2 } \\
\text { on right. Generalised weakness } \\
\text { of both (predominantly right } \\
\text { hand) upper limbs. Bilateral } \\
\text { trigeminal loss. }\end{array}$ \\
\hline P.W. & 44 & $\begin{array}{l}\text { Complete } \\
\text { D7 }\end{array}$ & 3 years & $\begin{array}{l}\text { Pain in right shoulder, loss } \\
\text { of feeling and power in right } \\
\text { upper limb. }\end{array}$ & $\begin{array}{l}\text { Dissociate sensory loss } \mathrm{C}_{5}-\mathrm{D}_{7} \\
\text { right. Weakness of right } \\
\text { upper limb. }\end{array}$ \\
\hline A.Ba. & 23 & $\begin{array}{l}\text { Incomplete } \\
\mathrm{L}_{4}\end{array}$ & I9 years & $\begin{array}{l}\text { Pain right shoulder. Loss } \\
\text { of feeling chest, right } \\
\text { shoulder. Cut right hand } \\
\text { while doing carpentry. } \\
\text { Sensory involvement to TI I } \\
\text { on left. }\end{array}$ & $\begin{array}{l}\text { Dissociate sensory loss right } \\
\text { arm, C3-D4 (Migraine, Bell's } \\
\text { Palsy). }\end{array}$ \\
\hline T.Mc. & 44 & $\begin{array}{l}\text { Complete } \\
\text { L4 }\end{array}$ & 8 years & $\begin{array}{l}\text { Progressive loss of pain } \\
\text { sensation in trunk and right } \\
\text { upper limb, lesser degree in } \\
\text { left with pain in shoulders. } \\
\text { Dissociation of hot and cold } \\
\text { and pin prick. }\end{array}$ & $\begin{array}{l}\text { Dissociate sensory loss } \mathrm{C}_{4}-\mathrm{D}_{4} \\
\text { on right, less marked changes } \\
\text { in left, pain in shoulder. }\end{array}$ \\
\hline J.Re. & 37 & $\begin{array}{l}\text { Incomplete } \\
\text { D6 }\end{array}$ & I year & $\begin{array}{l}\text { Pain at } \mathrm{D}_{4} \text {, loss of sensation } \\
\text { left arm leading to pain in } \\
\text { left arm. }\end{array}$ & $\begin{array}{l}\text { Dissociate left sensory loss, } \\
\mathrm{C}_{3}-\mathrm{D} 6 \text {, with global } \\
\text { weakness left hand. Late } \\
\text { minimal ascent } \mathrm{D}_{2} \text { on the right. }\end{array}$ \\
\hline J.Hu. & 20 & $\begin{array}{l}\text { Incomplete } \\
\text { D I I }\end{array}$ & 5 years & $\begin{array}{l}\text { Paraesthesia right arm, loss } \\
\text { of pain sensation in right } \\
\text { side of face. }\end{array}$ & $\begin{array}{l}\text { Dissociate sensory loss right } \\
\text { trigeminal, } \mathrm{C}_{5}-\mathrm{D}_{3} \text {. }\end{array}$ \\
\hline J.H. & 38 & $\begin{array}{l}\text { Incomplete } \\
\text { L I }\end{array}$ & $9 / 12$ & $\begin{array}{l}\text { Pain right upper limb and } \\
\text { numbness of right side of } \\
\text { the face. }\end{array}$ & $\begin{array}{l}\text { Bilateral trigeminal involvement } \\
\text { plus right } \mathrm{C}_{2}-\mathrm{L}_{\mathrm{I}} \text { and } \\
\text { left } \mathrm{C}_{3}-\mathrm{L}_{1} \text {. Weak right hand } \\
\text { intrinsic muscles. Later almost } \\
\text { total loss of power in left } \\
\text { upper limb resulting in total } \\
\text { incapacity. }\end{array}$ \\
\hline
\end{tabular}

lus right $\mathrm{C}_{2}-\mathrm{L}_{1}$ and total loss of power in left incapacity. 
TABLE I continued

\begin{tabular}{|c|c|c|c|c|c|c|}
\hline Name & $\begin{array}{l}\text { Age at } \\
\text { Injury }\end{array}$ & Level & $\begin{array}{l}\text { Interval to } \\
\text { New Symptoms }\end{array}$ & New Symptoms & $\begin{array}{l}\text { New Motor or } \\
\text { Sensory Signs }\end{array}$ & $\begin{array}{l}\text { Duration of } \\
\text { Follow up } \\
\text { After Injury } \\
\text { (years) }\end{array}$ \\
\hline E.F. & 55 & $\begin{array}{l}\text { Complete } \\
\text { D4 }\end{array}$ & 2 years & $\begin{array}{l}\text { Pain and weakness left arm } \\
\text { and hand. }\end{array}$ & $\begin{array}{l}\text { General weakness of whole left } \\
\text { upper limb. Absent reflexes. } \\
\text { Dissociate sensory loss C5-D } 4 \\
\text { on left. }\end{array}$ & 3 \\
\hline R.R. & 22 & $\begin{array}{l}\text { Complete } \\
\text { L4 }\end{array}$ & 2 years & $\begin{array}{l}\text { Loss of pain sensation in } \\
\text { right upper limb followed } \\
\text { by pain in right chest and } \\
\text { shoulder. Loss of power both } \\
\text { lower limbs. }\end{array}$ & $\begin{array}{l}\text { Dissociate sensory loss from } \\
\text { C3-L4. }\end{array}$ & 28 \\
\hline J.Hi. & 23 & $\begin{array}{l}\text { Incomplete } \\
\text { Dio }\end{array}$ & 6 years & $\begin{array}{l}\text { Pain in right chest followed } \\
\text { by loss of pain sensation and } \\
\text { hot and cold in right hand. }\end{array}$ & $\begin{array}{l}\text { Dissociate sensory loss between } \\
\text { C5-D ro on the right, similar } \\
\text { changes } 2 \text { years later on left. }\end{array}$ & 9 \\
\hline A.S. & I 4 & $\begin{array}{l}\text { Complete } \\
\text { D6 }\end{array}$ & 2 years & $\begin{array}{l}\text { Pain and sensory loss in } \\
\text { left upper limb. }\end{array}$ & Dissociate sensory loss $\mathrm{C}_{4}-\mathrm{D} 6$. & 33 \\
\hline P.B. & I5 & $\begin{array}{l}\text { Complete } \\
\text { D6 }\end{array}$ & I 6 years & $\begin{array}{l}\text { Loss of pain sensation in } \\
\text { right upper limb, pain in } \\
\text { right chest and neck followed } \\
\text { by similar changes on left. }\end{array}$ & $\begin{array}{l}\text { Dissociate sensory loss right } \\
\text { trigeminal to D6 followed by } \\
\text { similar changes on left with } \\
\text { generalised weakness of both } \\
\text { upper limbs. Commencing } \\
\text { in right hand with stepwise } \\
\text { progression. }\end{array}$ & 28 \\
\hline S.Wi. & I 8 & $\begin{array}{l}\text { Complete } \\
\text { D.8 }\end{array}$ & I year & $\begin{array}{l}\text { Pain in left arm, left side } \\
\text { of head and leg with global } \\
\text { weakness of left hand. Late } \\
\text { ascent two segments on } \\
\text { right. Then sudden } \\
\text { deterioration later. }\end{array}$ & $\begin{array}{l}\text { Dissociate sensory loss between } \\
\text { C5-D8. } 4 \text { years later sudden } \\
\text { deterioration with dense loss all } \\
\text { modalities C2-D8 with tremor, } \\
\text { dysphagia, hiccoughs and } \\
\text { paralysed left diaphragm. } \\
\text { C.T. scan confirmed cyst in } \\
\text { the medulla. }\end{array}$ & 4 \\
\hline
\end{tabular}


T.C. 46 Incomplete
D5

I year

G.Y. $\quad 58 \quad$ Complete D5

I 8 months

D.E.

I9 Complete D5

9/12

$\begin{array}{ll} & \text { remitted for many years } \\ & \text { then developed weakness } \\ & \text { in left hand. }\end{array}$

Pain in right shoulder

followed by partial loss of feeling in right chest.

Feeling of coldness in right arm accompanied by

difficulty in swallowing and talking.

in left hand.
Dissociate sensory loss between D4-D6.

Rotatory nystagmus, loss of upward gaze, paralysed palate, paralysed vocal cord. Global

weakness of right arm.

Complete loss of reflexes in

right arm. Dissociate sensory

loss below $\mathrm{C}_{2}$ on right,

minimal sensory changes on

left.

Sensory impairment to $\mathrm{C}_{5}$

which remitted then weakness

developed in interossei muscles

of left hand 17 years after

injury accompanied by minimal

sensory changes in $\mathrm{C} 8$

distribution. 
here 40 patients with post-traumatic syringomyelia, Table I. One was caused by a stab wound, two by gunshot wounds, the remainder by direct or indirect violence. We know of other patients who have developed this condition following spinal anaesthesia, osteomyelitis and thoracic disc protrusions but which have not been included in this study. The diagnosis had been made by neuroradiological investigations and operations in 22 patients Fig. I and in one of these a post-mortem confirmed the diagnosis. In two patients the diagnosis was made at operation, in one by neuroradiological investigation and in one patient at post mortem. In the remaining fourteen the diagnosis was made on clinical grounds alone. (See Table 2).

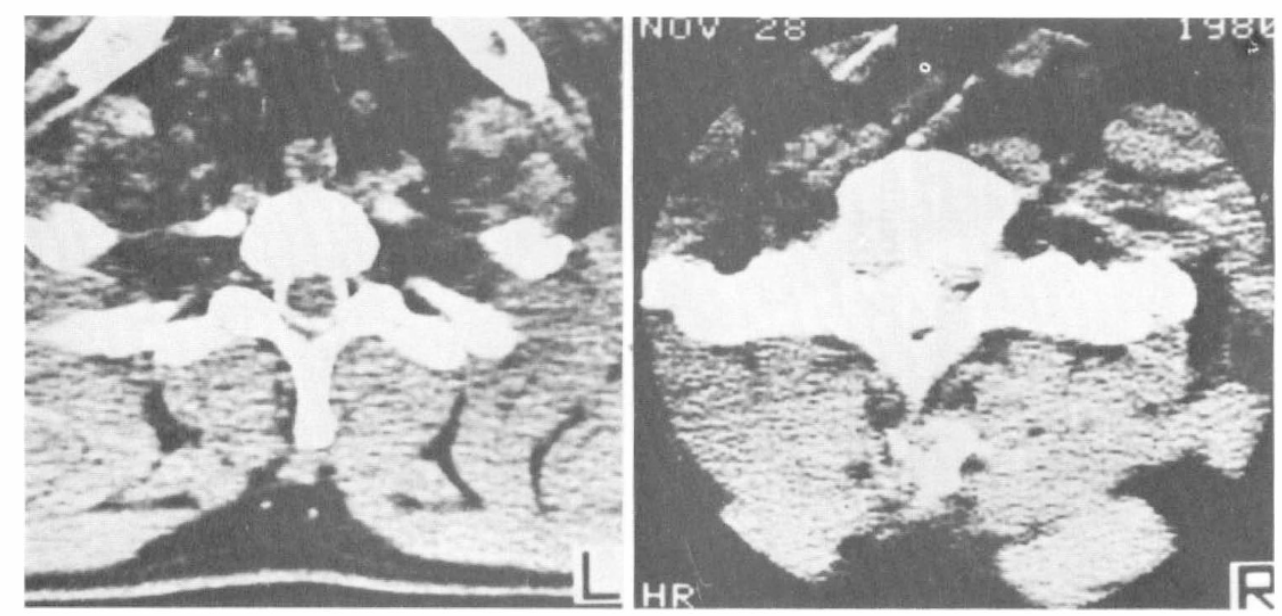

FIG. I

Augmented metrizamide enhanced computerised tomography.

a. Early scan shows dye around the dilated cord.

b. Eight hours later the dye has entered the cyst.

\section{Incidence}

The 40 patients out of 6,800 admissions to the National Spinal Injuries Centre only represents a proportion of the patients with this condition and the figure of 0.6 per cent is unrealistic. There are at least another ten traumatic cases not presented in this publication since the investigations or documentation are not complete.

A much more realistic figure can be obtained by looking at the incidence amongst 370 consecutive traumatic patients personally followed up by one of the authors over a ten year period (I970-1980), I66 cervical, I 54 dorsal, 45 lumbar, five not known. There were six patients in this series giving an incidence of $\mathrm{I} \cdot 6$ per cent, a figure similar to that obtained at Lyndhurst Lodge by Barnett et al. (1973), where they found that out of a series of $I, 387$ patients seventeen had this condition, giving an incidence of $I \cdot 2$ per cent. It should be noted that the period of study of the Lyndhurst Lodge series was between 1945 and I $97 \mathrm{I}$, a span of 26 years. This is longer than our own series, 1970 to 1980 , and our figure of $1 \cdot 6$ per cent is an under- 
TABLE II

Diagnosis

\begin{tabular}{|c|c|c|c|c|c|c|}
\hline & Confirmed & & & Not & Confirmed & \\
\hline $\begin{array}{l}\text { Neuroradiological } \\
\text { Investigations } \\
\text { and Surgery }\end{array}$ & $\begin{array}{l}\text { Neuroradiological } \\
\text { Investigations } \\
\text { Alone }\end{array}$ & $\begin{array}{l}\text { Post Mortem } \\
\text { Alone }\end{array}$ & $\begin{array}{l}\text { Operation } \\
\text { Alone }\end{array}$ & $\begin{array}{l}\text { Neuroradiological } \\
\text { Investigations } \\
\text { Negative }\end{array}$ & $\begin{array}{c}\text { No } \\
\text { Investigation }\end{array}$ & Total \\
\hline $22^{\star}$ & I & I & 2 & 6 & 8 & 40 \\
\hline
\end{tabular}

$\star$ One also had an autopsy. 
estimate since it is known that this condition can manifest itself as late as I 8 years after the onset of paraplegia.

\section{Level of Injury in Patients Developing the Condition}

Six cervical, 27 thoracic and seven lumbar patients developed post-traumatic syringomyelia. Few cervical injuries showed this condition, i.e. six out of 40 and this is in common with Barnett et al. (1973), who found only one cervical patient in their series of 17 .

In the early days few patients with cervical injuries were admitted to the National Spinal Injuries Centre. Sir Ludwig Guttmann (I976), in an analysis of the first 3,000 patients found 466 cervical, I,036 thoracic and 46I lumbar lesions, the rest being paralysed as a result of medical conditions. The mortality amongst the cervical patients was high so it might be argued that the cervical patients were not surviving long enough to develop this condition. This argument cannot be applied to the experience of the last ten years when there was, amongst I66 cervical patients referred to previously, a mortality rate of $\mathrm{I} O$ per cent at ten years, Ravichandran and Silver (I982). Once these patients survive the initial six weeks they can be expected to survive for twenty-five years. The small number of cervical patients who have developed post-traumatic syringomyelia thus represents a diminished risk in this type of patient of developing this condition. This has been confirmed statistically by observing that the proportion of cervical to thoracic lesions among the syringomyelia cases was significantly less than among the patients as a whole $(P<0.00 \mathrm{I})$ whereas the proportion of thoracic and lumbar lesions did not differ $(P>0.05)$. Unfortunately, there are not enough cases to determine if patients with thoracic injuries are particularly liable to develop this condition, compared with patients with lumbar injuries.

In view of the rarity of patients with cervical lesions developing syringomyelia, we are presenting the history of one case, K.A., in detail:-

In I966 a 59-year-old female sustained a gunshot wound of the spine causing tetraplegia incomplete below $\mathrm{C}_{5} / 6$ and complete below C8. A laminectomy operation was performed. She was admitted to the 'Young Chronic Sick Unit' as a long-term patient. In I 974 she began to notice a loss of sensation and weakness of the whole of the left arm and also a shooting pain in the left side of the neck and shoulder radiating to the hand. She developed further weakness of her left upper limb in the shoulder and elbow and her previously partially paralysed hands had become more wasted and weaker.

The tendon jerks were normal in the right arm but were depressed in the left and were absent in both lower limbs. Sensation was impaired below the third division of the trigeminal nerve on the left to involve the whole of the left arm to all modalities and in the right arm below C8.

A myelogram showed a block at the lower border of the $\mathrm{T}_{3}$ vertebrae and the cervical cord was dilated in the $\mathrm{C}_{5} / \mathrm{C}_{7}$ region. There was an irregular narrowing of the subarachnoid space at the site of the previous trauma. An operation was not carried out at this stage and she was discharged to a nursing home. Following a bumpy car ride she noticed a further deterioration in her condition. Surgery was then carried out and the cord appeared to have degenerated into a system of multiple cysts which communicated with one another to a considerable extent. Longitudinal incisions were made in the cord in the $\mathrm{D}_{\mathrm{I}} / 2$ region, the cysts being incised on either side to reach the subarachnoid space anteriorly. She developed a cerebrospinal 
fluid leak but following a further operation this healed. She was discharged to long-term care elsewhere, and re-admitted in January 1977 with hypothermia and died on I4.I.77. A post mortem examination was carried out:-

\section{Macroscopic appearances of the spinal cord}

At the cervicothoracic level the theca was bound down by dense fibrous adhesions to the cord and bone was adherent to the meninges. In the upper cervical region the cord showed marked flattening of the posterior columns and also a slit-like cavity involving grey matter, particularly the anterior horn on the left side. In the midcervical region this cavity was more pronounced. At $\mathrm{C}_{5}$ the whole cord was shrunken, with extensive bilateral slit-like cavitation. At the site of the dense meningeal adhesions, the possible site of the original bullet wound, i.e. the lower cervical, upper thoracic region, the cord was completely replaced by multiple smooth walled cavities with intervening septae of dense fibrous tissue and grey, probably gliotic tissue. Immediately below this mid thoracic level more cord substance was visible but at least two separate cystic cavities were present. In the lower thoracic and upper lumbar levels there was a single, central, smooth-walled cavity. Below this there again appeared to be multiple cavities separated by septae. At about $\mathrm{L}_{3}$ level the cord was flattened antero-posteriorly and had a single slit-like cavity. At the mid-lumbar level there were no obvious syringomyelic cavities but there was a thin grey area of possible demyelination of the gracile tract bilaterally and also greyness in the pyramidal regions. In the conus medullaris there was a central cruciate cavity probably the central canal. The anterior roots generally appeared to be shrunken and grey. Fig. 2.

Comment: After a delay of eight years this patient developed a typical syndrome of post-traumatic syringomyelia which extended both above and below the level of her initial injury.

We know of two other cases, not included in this series, who initially had cervical lesions who developed this condition. Details of one of these is presented:-

On 30.9.76 E.H., a nineteen-year-old male, was involved in a road traffic accident. He sustained a fracture dislocation of C6 resulting in tetraplegia incomplete below $\mathrm{C}_{5}$, complete below $\mathrm{D}_{3}$. There was considerable recovery of power in both his hands, particularly on the right and a little on the left. During December I98I he developed severe interscapular pain with increasing numbness and weakness of the right arm and hand. Both his hands developed weakness in previously strong muscles. He developed sensory loss over the whole right hand side of the body including the trigeminal distribution, with associated tendon reflex loss.

\section{Time of onset of post-traumatic syringomyelia}

The time of onset of this condition is extremely difficult to determine, especially in retrospect, as it was only after the publication of Barnett et al.'s paper in 1966 describing the condition and his subsequent studies showing that it could be arrested by operation, that we began to consider its presence in patients who were then referred for investigation at neurosurgical centres. We are now diagnosing the condition earlier and more frequently.

We have made an effort by studying the notes and questioning the patients to determine the time of first presentation, but it is obvious that in 


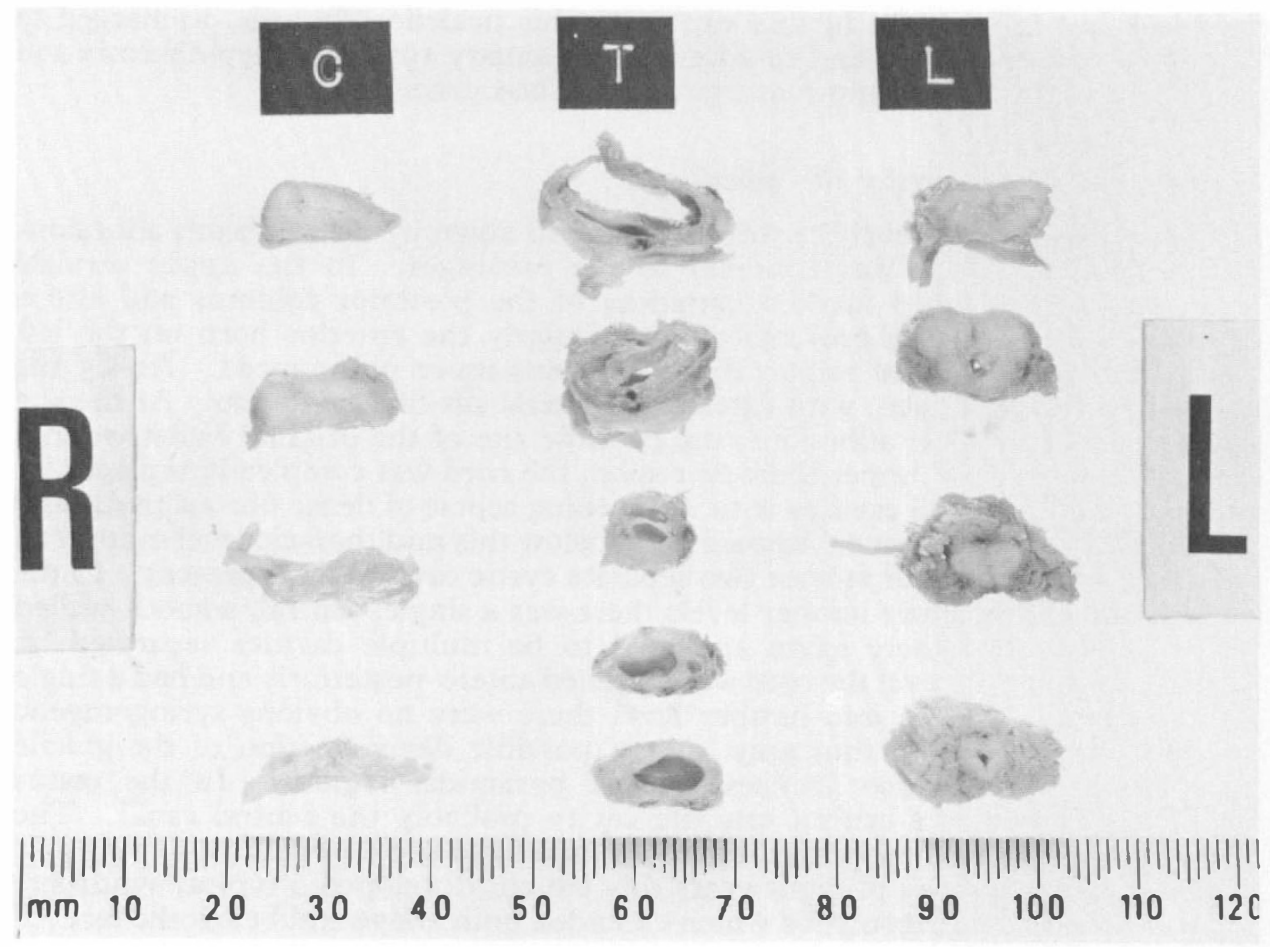

FIG. 2

Post Mortem on K.A. Transverse sections of the cord at cervical, thoracic and lumbar levels. There is cavitation in the cord from the cervical to the lumbar region, in part multilocular. Note, it extends well below the site of the initial injury.

patients whose condition presented some 25 years ago that inaccuracies are present, particularly when the onset was insidious. To avoid doubt we suggested taking the date of onset of the condition as being the time when unequivocal sensory loss was present. Even today when we are more aware of the disorder, and are referring patients for early investigation, we are still surprised by the atypical way in which the condition may present.

In nine patients it presented at a year or less and in four as late as I 8 years after injury. The earliest case, T.M., was observed to have tingling of the right hand at two months followed by loss of sensation at 8 months and wasting of the interosseous muscles at I I months. The diagnosis was not entertained and subsequently electromyography and nerve conduction studies were performed as he was thought to have an ulnar nerve lesion. The diagnosis was not confirmed and it was only some I4 months after injury, after coughing suddenly, that he developed pain together with a wider area of sensory loss. The diagnosis of syringomyelia was confirmed by a myelogram and at operation.

We could not detect any significant difference in the time of onset between patients with complete or incomplete lesions. There were 22 in one group and 18 in the other and statistical analysis showed no significant 
difference. ( $P>0.05$; Students $T$ test). We subjected Barnett's figures to a similar analysis and, this too, failed to show any significant difference.

\section{Initial Manifestations}

Despite the fact that the development of fresh symptoms and signs above the level of the initial injury would appear to be a frightening experience, only Io patients requested a special appointment at the hospital because of this. Out of these ten patients seven complained of pain, two of weakness of the hand, and two of sensory loss. In the remaining patients the condition was detected at routine examination when they were seen for check up, Table 3 .

TABLE III

\begin{tabular}{lr}
\hline \multicolumn{2}{l}{ Initial Manifestations } \\
\hline Pain & 25 \\
Sensory Loss & 8 \\
Motor Weakness & 2 \\
Other & 5 \\
\hline
\end{tabular}

In 40 patients pain was the commonest presenting symptom. Seventeen had continuous pain, three had pain on straining or coughing and one had both. Eleven patients were found to have an extension of their sensory loss above the level of the lesion; two patients had weakness of the hand and four had paraesthesiae. While the signs and symptoms mentioned above brought the patient to hospital, re-examining them and studying their notes has revealed more subtle symptoms such as excessive sweating, early loss of previously present reflexes and minor alterations in muscle power that were attributed to arthritis around the shoulder girdle. Others had loss of sensation attributed to a carpal tunnel syndrome, pain or difficulty with swallowing (and one patient who presented with 'painless' dislocated shoulder, not included in the series). (Fig. 3).

\section{Pain}

Pain was the commonest presenting feature. In 25 patients it was an early finding, and of these, seven requested consultation at the hospital because the pain was severe. In the remaining 20 it was noted during routine examination. Only ten patients had no pain at any time and one of these developed pain for a short period only after surgery had been performed upon the syrinx.

In 12 patients the pain was localised centrally over the lower cervical or upper thoracic spinous processes. It radiated into the arm or trunk in all except one patient. In two patients the limbs were not involved, the pain being in the chest or abdominal wall only, while one patient with a cervical lesion presented with pain in the throat.

The character of the pain was variable, the commonest being a dull ache as seen in 20 patients. It was precipitated by coughing in 12 patients and by exercise in six. It is striking that a small number of patients clearly dated the onset of pain from an episode of coughing, straining or 


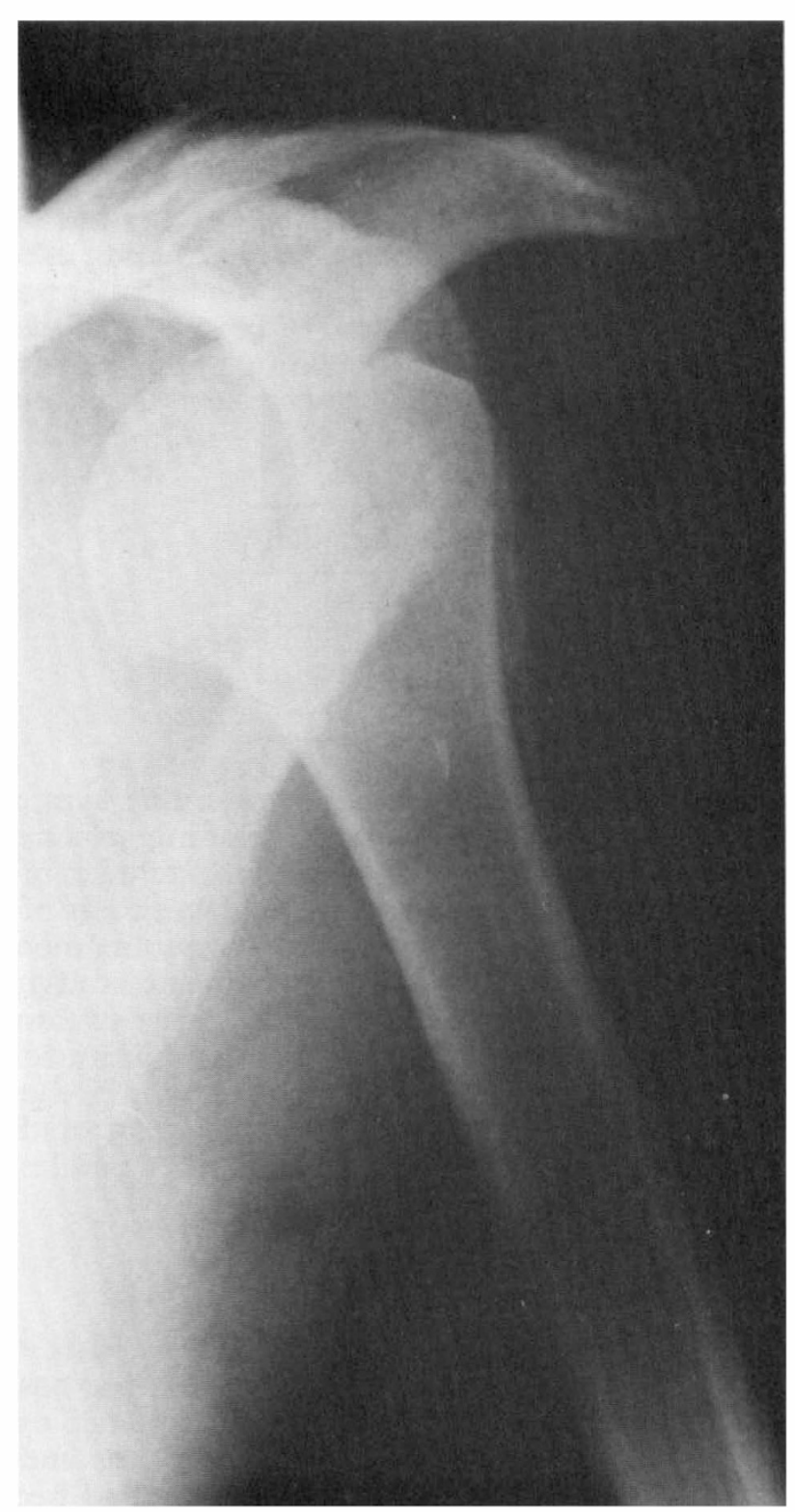

FIG. 3

Painless dislocated shoulder in a paraplegic patient. In a normal person this would be extremely painful.

strenuous exertion. While the pain was usually a dull ache it could be stabbing or burning in nature. When it occurred at or below the level of the cord lesion it was indistinguishable from root pain. When the pain occurred in normally innervated areas of skin well above the cord lesion it was more significant. A striking symptom was the description in four 
patients of an itch that could not be scratched, in the anaesthetic areas. We have not seen the dramatic progression described by Barnett et al. (I973), of the pain ascending from the level of the lesion, followed by an area of numbness.

The pain fluctuated in intensity and sometimes the patient was free from pain for several days. It was aggravated by tension or bouts of fever but could sometimes be relieved by dexamethasone or an injection of a local anaesthetic. Only one patient, who had also had a severe head injury, became addicted to narcotics.

The most striking feature was the dramatic relief obtained by surgical drainage of the cyst. In some cases the relief of the pain was noted when they recovered from the anaesthetic but in others it took some weeks to disappear. The pain recurred if the drainage became blocked, and was relieved when drainage was re-established. In only one patient was the pain precipitated by the operation, but in this case the pain was of short duration.

\section{Sensory Disturbance}

The commonest presenting clinical sign was sensory disturbance, occurring at some stage in virtually every patient. Indeed we would say that its absence would make the diagnosis extremely unlikely, in view of the location of the cyst, demonstrated at post mortem and by myelography, at the base of the posterior horn of grey matter. Sensory changes were very striking in all the patients apart from one in whom it was difficult to detect, even when motor manifestations were well established. Only two patients were so distressed that they sought help from the hospital; one had cut his hand while sawing wood, and the other was frightened by increasing sensory loss. Two other patients first noticed severe swelling of their arms; in one it was due to a Charcot shoulder but the other had cellulitis. Presumably he had neglected a small cut or cigarette burn on his hand. When the swelling subsided following a course of antibiotic therapy he was found to have considerable sensory loss. This swelling has been described in classical syringomyelia by Morvan ( 1883 ). Apart from these, the majority of patients were surprisingly little disturbed by the sensory loss, and it was found at routine check up examination.

\section{Mode of Progress}

The progress of the sensory loss tends to fall into clearly defined patterns. Firstly, in the majority of patients the sensory loss began at the site of injury and ascended from there to higher levels, the progress usually being insidious. Secondly, in six patients it took place in sharply defined steps. The progress stopped for an interval of months or years and then suddenly following an episode of straining or coughing, the lesion ascended a variable number of segments, sometimes overnight. Thirdly, in I 4 patients the pattern was different, presenting with an area of sensory loss over the face or upper limbs with an area of intact sensation between this and the spinal cord lesion, the two gradually merging.

\section{Speed of Progress}

The speed and direction of progress of the sensory loss was variable in some 
patients taking some years to ascend and spread. Conversely, in others there was a rapid onset and within a matter of hours the condition had spread from the trunk to involve the whole of the upper limbs. In T.G. it presented with a band of numbness in the $\mathrm{C} 8$ distribution and, overnight (following a day's vigorous physiotherapy), it had spread from $\mathrm{D}_{7}$ to involve the whole of the upper limb, involving I I segments. He was at this time undergoing his initial programme of rehabilitation at the National Spinal Injuries Centre, Stoke Mandeville Hospital.

In 12 patients the sensory loss spread to involve the face. No correlation could be found between the duration of the condition and the distance spread. Some patients with cervical lesions did not show any involvement of the face, although they had shown other changes for many years. Conversely, J.H. who had a lumbar lesion, showed within a year a rapid ascent to involve both the upper limbs and face. We did not find the relationship of pain described by Barnett et al. (1973) who found that the pain preceded the sensory loss and was associated with, or was gradually replaced by, a sensation of numbness. Some patients on questioning remembered that they had observed either excessive sweating in areas subsequently shown to be involved above the level of the lesion or, more rarely, the sweating disappeared. However, sweating disturbance in patients with spinal cord lesions is such a common occurrence above and below the level of the lesion that fluctuations in its intensity, when significant, is difficult to assess, except in retrospect.

\section{Character of the Sensory Loss}

The features of the sensory disturbance were predominantly spinothalamic. Loss was not total or uniform. There was sometimes loss of both deep and superficial pain sensation as shown by the development of Charcot joints. This is particularly liable to occur in these patients as they place undue strain upon their upper limbs which they use to transfer. In other patients deep pain was preserved and one, P.M., developed a painful tennis elbow beneath the anaesthetic skin. S.W. showed severe loss of all modalities and developed pseudo-athetosis and intention tremor in the left upper limb.

There was a dissociation between the temperature modalities so that sometimes cold appreciation was preserved and heat appreciation lost and sometimes the converse. The dissociation over the face was a special situation (Table 4). Some of the patients showed a classical Dejerine (I9I4) loss whereby peripheral areas of the face lost their sensation, the nose or lip being spared. The onionskin preservation has been described by Dejerine and is indicative of a lesion in the descending spinal tract of the Vth cranial nerve in the spinal cord. We also noticed loss of taste over the anterior two-thirds of the tongue associated with this loss. Appreciation of taste requires normal sensation over the tongue, mediated by the $V$ th cranial nerve and its loss does not indicate a lesion of the chorda tympani.

A further observation was that these patients showed patches of normal sensation in little islands of skin that were otherwise anaesthetic. Conversely one patient showed an island of total sensory loss. 
TABLE IV

Facial Involvement

\begin{tabular}{|c|c|c|c|c|c|c|c|}
\hline \multicolumn{2}{|c|}{ Level Name } & \multirow{2}{*}{$\begin{array}{c}\begin{array}{c}\text { Time since } \\
\text { injury } \\
\text { until symptoms } \\
\text { developed }\end{array} \\
\text { I }\end{array}$} & \multirow{2}{*}{$\begin{array}{c}\begin{array}{c}\text { Time since } \\
\text { injury } \\
\text { until facial } \\
\text { involvement }\end{array} \\
2\end{array}$} & \multirow{2}{*}{$\begin{array}{c}\begin{array}{c}\text { Interval from } \\
\text { symptoms } \\
\text { developing to } \\
\text { facial involvement }\end{array} \\
\text { Presenting }\end{array}$} & \multicolumn{2}{|c|}{ Dejerine Bilateral } & \multirow{2}{*}{$\begin{array}{c}\text { Non } \\
\text { Dejerine } \\
+\end{array}$} \\
\hline C6 & S.I. & & & & & + & \\
\hline C6 & S.K. & I5 & I 7 & 2 & + & & \\
\hline $\mathrm{C} 8$ & B.H. & 13 & $2 \mathrm{I}$ & 8 & + & & \\
\hline D4 & P.M. & 8 & 12 & 4 & & & + \\
\hline D5 & I.D. & I I & 15 & 4 & & & + \\
\hline D6 & P.B. & I6 & 22 & 6 & & + & + \\
\hline D6 & J.D. & 9 & I I & 2 & & + & + \\
\hline $\mathrm{D}_{7}$ & W.W. & 7 & 17 & IO & & & + \\
\hline DI I & J.Hu. & 5 & 9 & 4 & & & + \\
\hline DII & G.B. & 19 & 36 & I 7 & + & & \\
\hline Di2 & G.V. & 2 & 2 & Less than I year & & + & + \\
\hline $\mathrm{L}_{\mathrm{I}}$ & J.H. & I & I & Less than I year & & + & + \\
\hline
\end{tabular}




\section{Variability}

Daily variations occurred in the sensory loss, particularly in the facial distribution and some striking remissions occurred. One patient D.E. who had mild bilateral sensory loss, completely remitted, but many years later he developed motor weakness. Remissions could be induced by dexamethasone and by surgery.

\section{Motor Involvement}

Motor weakness was not a common presenting feature. Only three patients showed this as a first manifestation but the majority of the patients, (28), showed it at some stage (Table 5). This was lower motor neurone in type. Rarely it was preceded by exaggerated reflexes although this usually disappeared as the condition progressed. In patients with complete lesions, weakness could only be seen above the level of the lesion, usually in the upper limbs. The onset of weakness could be both insidious and subtle. The patients did not usually complain until their attention was drawn to the weakness when specifically questioned and tested and one patient only realised that there had been weakness when after surgery he found his hands were much stronger.

TABLE V

\begin{tabular}{lr}
\hline \multicolumn{1}{c}{ Motor Weakness } \\
\hline Unilateral & IO \\
Hand & 7 \\
Whole upper limb & I \\
Shoulder only & I \\
Elbow & 6 \\
Bilateral & I \\
Upper limb only & I \\
Lower limb above level & I \\
Upper and lower limbs in & I \\
Both arms + I leg in a paraplegic \\
Both arms + 2 legs in a quadriplegic \\
No weakness & Total \\
\hline
\end{tabular}

N.B. From the above:

Tetraplegic helplessness with bilateral involvement

So severely and suddenly affected in one arm as to be totally dependent

In ten patients it was first observed in the thenar and interosseous muscles of the hanci. These patients noticed difficulty in gripping and in fine movements. In two patients the weakness and wasting were so severe that a diagnosis of ulnar nerve lesion was considered. They were referred for electromyographic studies and one had his ulnar nerve transplanted before the spinal cyst was diagnosed. The correct diagnosis may be difficult to establish since both conditions can co-exist. Many patients lean 
on their elbows in any case and the anaesthesia from the syrinx can mask the pain of the ulnar neuritis.

In five of the ten patients, weakness and wasting was not restricted to the hand alone but progressed to involve the elbow and shoulder muscles. For example, J.B. showed such severe weakness of his whole hand as to render his upper limb virtually useless so that he stopped using a car; as his wife could not drive he became totally housebound. One patient, (J.H.) had bilateral involvement, one hand was weak and then after an interval of 4 years he developed severe weakness in the opposite arm and progressed to the condition of quadriplegic helplessness (described by Barnett). It can be life threatening as in high lesions it can involve the diaphragm.

In seven patients the weakness involved the whole upper limb from the outset. In further patients it did not present in the hand but in one it

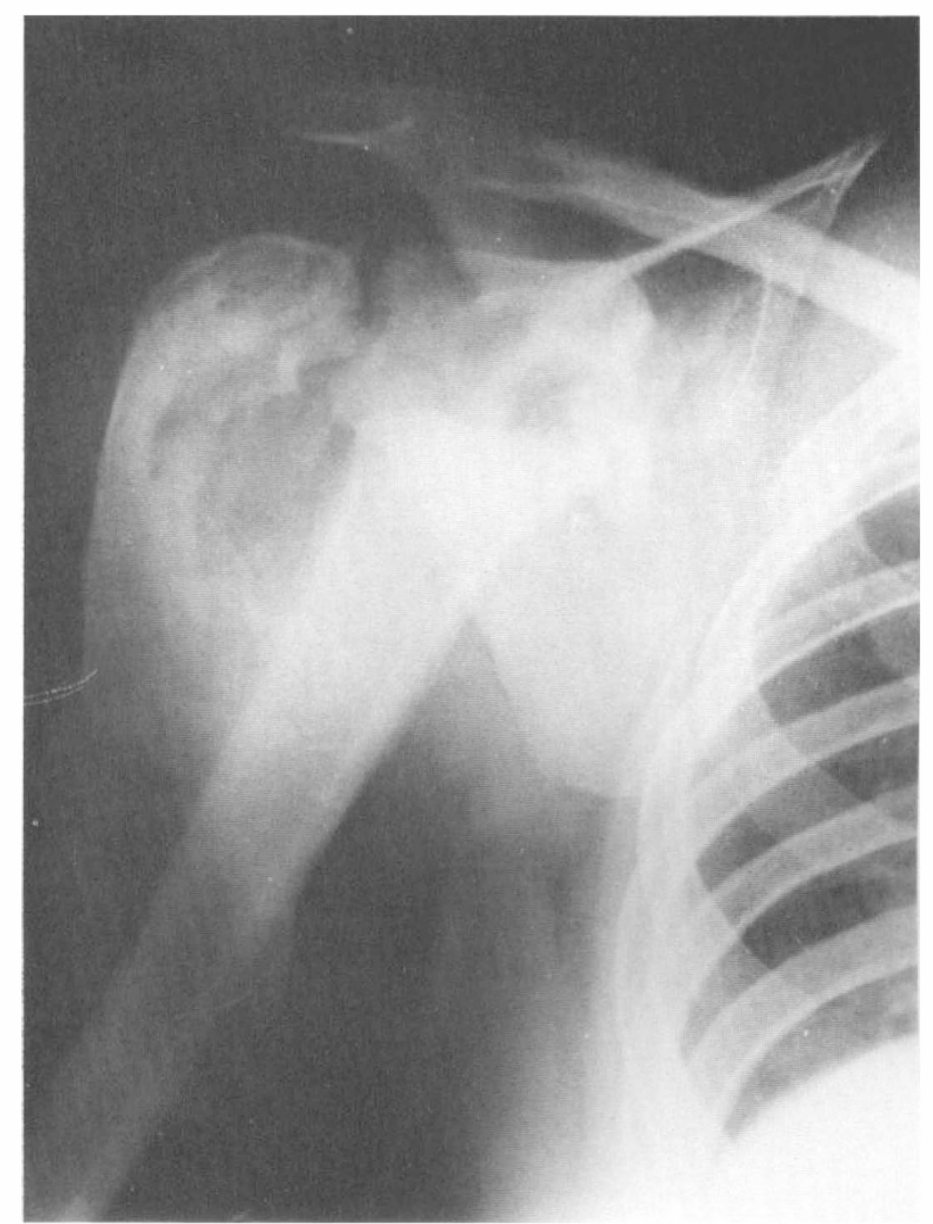

FIG. 4

Severe, painless Charcot joint in D.K. 
was localised mainly to the shoulder girdle and in another to the elbow in the triceps muscle. In 6 patients weakness and wasting spread to the other side, often beginning in the small hand muscles.

In patients with a complete cord lesion the weakness appears above the cord lesion, usually in the upper limbs. However, in a patient with a low cord injury the weakness may appear in the lower limbs. R.R. originally

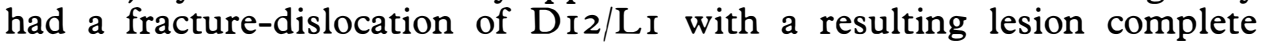
below L4. He experienced a deterioration of power initially in his knees and then in his hips. Sensory loss spread up to his neck with pain in his shoulders. He also experienced much pain and spasm in his left knee and ultimately underwent cord section for pain at another hospital. This confirmed the diagnosis of syringomyelia, but unfortunately the pain recurred in the perineum a few years later.

In contrast to the preceding patients with complete cord lesions a small number of patients with incomplete cord transections showed a deterioration in power below the level of the cord lesion. In two patients with bilateral involvement there was also involvement of the lower limbs.

In D.K., an incomplete paraplegic at the Di2 level, upper limb weakness of the right side was the first to appear. This predominantly involved the shoulder, resulting in a Charcot joint. (Fig. 4). The left arm was likewise affected but he lost sensation bilaterally below $\mathrm{C}_{2}$. His cyst thus extended above and below the level of the lesion including both sides of the cord, sparing the conus reflexes. In B.H., an ambulant tetraplegic, the weakness involved all four limbs making walking difficult. In this case too there was loss above and below the level of the cord lesion.

\section{Bilateral Involvement}

In the vast majority the presentation was unilateral but two patients showed bilateral changes when the condition presented. Other patients rapidly developed bilateral changes. (Table 6). Only twenty-five patients developed this condition. The side that presented first remained the most severely affected. It could occur at any stage. The commonest manifestation was sensory change; the least common was reflex changes and motor loss. It can easily be appreciated why sensory changes are the commonest manifestation in view of the finding of the cyst at the base of the posterior horn of grey matter. Williams (1979) has postulated that in idiopathic syringomylia (by the time the cyst has grown anteriorly large enough to cause motor weakness of a lower motor neurone type) sensory changes should be present on the other side. However, this only occurred in our

TABLE VI

\begin{tabular}{lr}
\hline \multicolumn{2}{c}{ Bilateral Involvement } \\
\hline Sensory & 2 I \\
Absent reflex & I \\
Motor & 8 \\
Total with bilateral involvement & 25 \\
\hline
\end{tabular}


series in 13 of the patients, approximately half. The others only showed ipsilateral weakness and sensory loss. Conversely, there were a small number of patients (4) who had bilateral sensory loss without showing any motor weakness. The only rational explanation for these findings is that the pathology differs from that found in classical syringomyelia and does not consist of a single large cyst but multiple cysts that intercommunicate and ramify throughout the different parts of the cord. This has been found both by myelography and at post mortem.

\section{Brain Stem Involvement}

Only a few patients with brain stem involvement have been described in the literature.

However, some of our patients with proven cysts have had a variety of symptoms from the brain and brain stem which might be attributable to brain stem involvement, such as dysphagia, perversion or loss of taste. Some have had migraine of an unusual type, one has had atypical Bell's palsy and two patients have developed deafness after the cyst manifested itself. However, in both cases this was shown to be peripheral in origin. D.R. had progressive deafness but a C.A.T. scan of the brain excluded syringomyelia, and auditory-evoked potentials showed that this deafness was peripheral and not central in origin. Three patients have had unequivocal clinical evidence of brain stem involvement, in two substantiated by C.T. scans.

G.Y. (Aged 58). He ustained a fracture-dislocation of $\mathrm{D} 4 / 5$ on II.IO.6I, when a sack fell on him causing a complete spastic paraplegia below D5. Lumbar puncture showed a complete block. In 1963 he experienced a cold feeling in his right arm followed by 'pins and needles'. Four months later he was referred to a neurosurgeon as he had developed difficulty in speaking. He had nystagmus, preservation of normal sensation over the face, the palate deviated to the left and there was a right laryngeal nerve palsy. He had global weakness of the right arm and there was impairment of all modalities of sensation apart from figure writing in the right arm. At a later stage he developed impairment of sensation in $\mathrm{C}_{7}$ and C8 dermatomes on the left side to two point discrimination. Tendon reflexes were lost in all four limbs. A diagnosis of brain stem ischaemia was made and he was transferred to the National Spinal Injuries Centre, Stoke Mandeville Hospital. In I969 (aged 65) he died of pneumonia and cardiac failure. Macroscopic section of the brain did not confirm a cyst. Unfortunately, sections were not preserved for histolog $\mathrm{y}$.

\section{Spinal Cord}

The dura and leptomeninges showed an area of scarring extending for $4 \mathrm{cms}$ over D5 segment and partly the segments above and below this. The spinal cord showed atrophy from D2 down to the conus. The anterior spinal artery could be identified throughout most of the cord except where it was obscured by the traumatic scar. Transverse slices through the cord were made at each segmental level. A small syrinx began at $\mathrm{C}_{2}$, situated in the right posterior fossa and neighbouring posterior column. This expanded at $C_{3}$, involving most of the right posterior column and all of the right posterior horn. The transverse slices caudal to this showed the extent of the syrinx which could be seen as far as Di segment. D2 appeared to be atrophied with a small trace of syrinx which could also be seen 
in $\mathrm{D}_{3}, \mathrm{D}_{4}, \mathrm{D}_{5}$ and $\mathrm{D} 6$ showing atrophied cord segments deformed and associated with connective tissue fibrosis. From $\mathrm{D}_{7}$ down to D I t the cord was atrophied generally but not apparently due to direct trauma. Di2 showed some atrophy suggesting gliosis of the cord of the lesion above. The lumbar and sacral cord were normal apart from pyramidal tract degeneration.

Comment. In his case the clinical features were unequivocally those of brain stem involvement. The brain section macroscopically did not show a cyst but this could easily have been missed and, unfortunately, the brain was not preserved for detailed histology.

\section{$A$ further case is presented}

In $1976 \mathrm{~S}$.W. aged I 8 sustained a complete lesion below D8 as the result of a fracture of his fifth upon sixth thoracic vertebrae due to a motor cycle accident. One year after injury he developed partial anaesthesia of a spino-thalamic type in his left arm between $\mathrm{C}_{5}$ and D8 with minimal weakness of his left hand. As it was causing him little disability he was not investigated further. Four years later he suddenly developed dense sensory loss in the left upper limb with pain in the left shoulder, hiccoughs and dysphagia. Examination showed him to have surprisingly well preserved power in the left upper limb with a paralysed left diaphragm although he had little use of the left arm. He had bilateral depressed corneal reflexes and dense sensory loss involving all modalities including posterior column of the whole of the left upper limb from $\mathrm{C}_{2}$ down to D8. There was

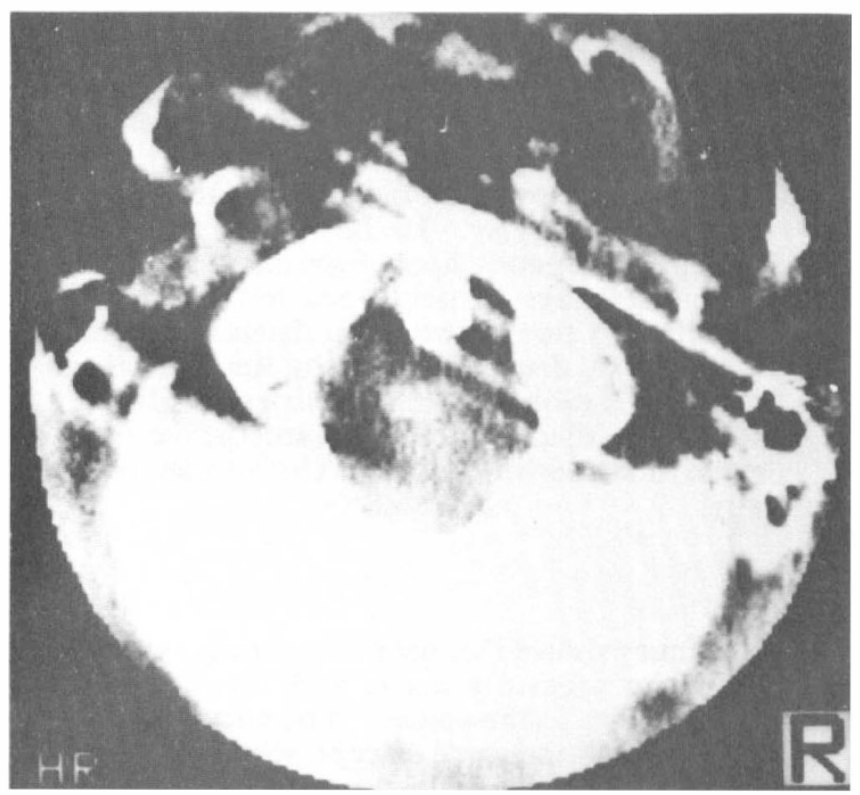

FIG. 5

S.W. Late matrizamide enhanced computerised tomography scan at base of skull, odontoid anteriorly, occipital condyles laterally, basi occiput posteriorly with metrizamide in the syrinx. 


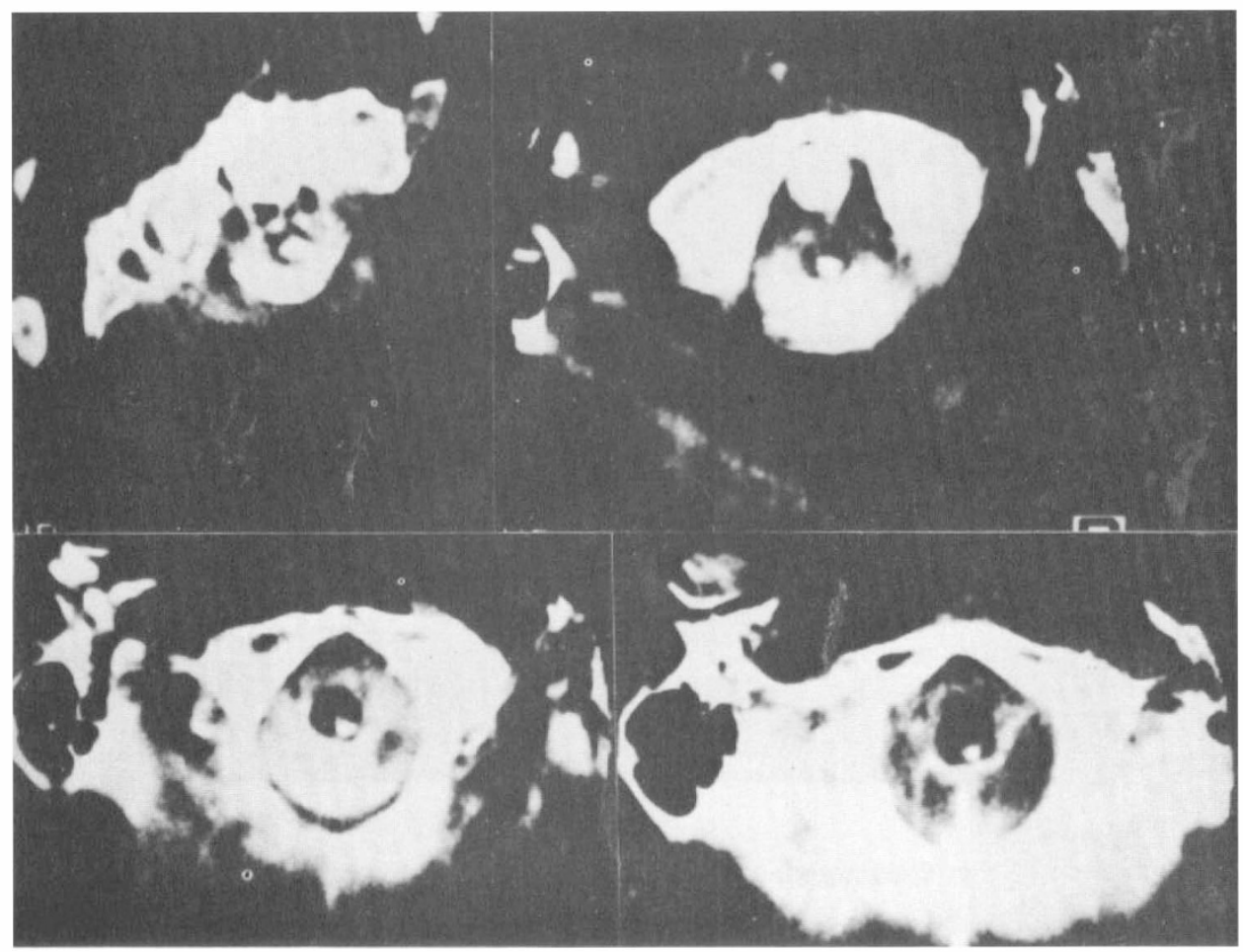

FIG. 6

Late metrizamide enhanced computerised tomography to show the syrinx extending through the foranem magnum into the brain stem.

Top right at the occipital condyles, syrinx clearly visible. Bottom right, through the foranum magnum, the cyst is extending into the brain stem.

tremor of the left arm that was only partially corrected when he concentrated. There was intention tremor. Scan revealed that the upper thoracic cord was dilated with a cyst in the medulla. (Figs. 5, 6 and 7.)

\section{Natural History}

There have been only 73 cases described in the literature. The largest series described by a single author until now was I 7 cases. (Barnett et al., I973). The present series of 40 cases does enable us to amplify and delineate the condition more fully.

\section{Conclusions}

I. These 40 patients certainly do not represent the total number of patients with this condition since at this centre many patients were lost to follow up and it is weighted by those cases seen more recently when active investigation and exploration has been carried out. 


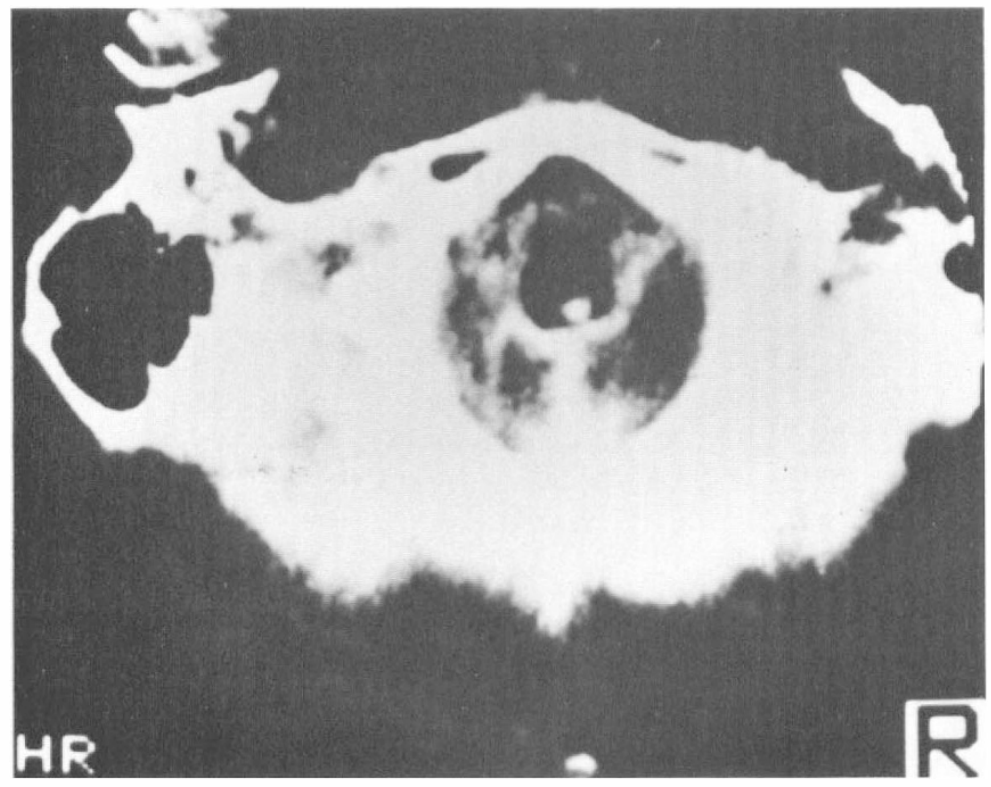

FIG. 7

Bottom right of Fig. 6, enlarged, showing the cyst extending into the brain stem in S.I.

Consequently the progress has been modified by treatment. In many cases it has been arrested but a small number have deteriorated. We have encountered the condition within two months or as long as 30 years after injury.

2. Untreated, all the cases have progressed either slowly or rapidly, some to severe disability. At least three had brain stem involvement. Two progressed to quadraplegic helplessness.

3. There is no way of predicting from the extent, the level, the severity of the injury or its aetiology, how quickly or how slowly the condition will progress, but it does do so and frequently the other side is involved.

4. Secondary changes in the joints are common.

5. From the post-mortem studies it is clear that several cysts may exist and the condition can progress both upwards and downwards confirming the clinical findings.

6. Clinical extension caudally has been found in three patients. In one patient the cyst was demonstrated at post-mortem extending well below the level of the lesion; the other post-mortem showed extensive atrophy of the cord below the fracture site of maximum injury.

7. Remissions, particularly sensory, may take place for as long as is years. Surgical treatment does not always improve the condition of the patient and two are known to have deteriorated after surgery.

These findings support the view tnat at least in some of the patients an injury occurs to the cord not only at the site of maximum trauma but also at a distance from it and as time passes, cystic changes supervene 
in those damaged areas and that as the cysts increase in size they compress the adjacent neural tissue causing symptoms and signs.

Acknowledgements: We would like to thank Dr H. L. Frankel, Mr I. Nuseibeh, Mr D. O. Hancock and Dr J. J. Walsh for generously allowing us to present the details of the patients under their care. We would also like to thank Dr L. W. Duchen and Dr Trevor Hughes for the post-mortem reports, Dr B. E. Kendall for the computerised tomography scan pictures and Professor L. T. D. Symon for his help and advice.

\section{SUMMARY}

The clinical features of 40 patients with post-traumatic syringomyelia are described. The diagnosis was confirmed in 26 patients by neuroradiological investigations, operation or post-mortem examination. In the remaining I 4 it was a clinical diagnosis. There were six cervical, 27 thoracic and seven lumbar patients. The incidence was thought to be at least $\mathrm{I} \cdot 6 \%$ of traumatic injuries. The time of onset was between two months and eighteen years and no difference was found in the time of onset between complete and incomplete lesions. The commonest initial manifestation in 25 patients was pain, sensory loss in eight patients and motor weakness in two patients. The condition was bilateral in 25 and involved the trigeminal territory in 12 patients. Three patients developed brain stem involvement. The natural history of this condition is discussed.

\section{RÉSUMÉ}

On décrit les caractéristiques cliniques des 40 patients avec de la syringomyélie post traumatique. La diagnose était confirmée par des investigations neuro-radiologiques, par des opérations ou par l'autopsie. Les autres I4 cas étaient des diagnoses cliniques. Il y avait 6 patients avec des lésions cervicales, 27 thoraciques oy 7 lombaires. L'incidence était pensée d'être au moins $I \cdot 6^{\circ}$ des lésions traumatiques. Le tempe d'attaque était entre deux mois et I 8 ans. On n'avait pas trouvé une différence entre des lésions complètes et incomplètes dans le temps d'attaque. L'Initiale manifestiation la plus commune était la douleur pour 25 patients, la perte sensoriale pour 8 patients et pour 2 patients la faiblesse motrice. La condition était bilatérale pour 25 patients et 12 patients avaient une implication du territorie du trijumeau. Trois patients développaient une implication du tronc cérébral.

L'histoire naturelle de cette condition est discutée.

\section{ZUSAMMENFASSUNG}

Es werden von 40 Patienten die klinischen Merkmale einer postraumatischen Syringomyelie beschrieben. Die Diagnose wurde bei 26 Patienten durch neuro-radiologische Untersuchungamethoden, durch Operation oder Obduktion bestaetigt. Bei den uebrigen I4 Faellen handelt es sich u m eine klinische Diagnose. Das Patientengut umfasste 6 cervicale, 27 thoracale und 7 lumbale Laesionen. Man nimmt an, dass das Auftreten mindestens $\mathrm{I} \cdot 6^{\circ}$ o der traumatischen Verletsungen susmacht. Die Zeit bis zua Auftreten betrug zwischen 2 Monaten und I 8 Jahren. In der Zeit des Auf tretens fand man keinen Unterschied zwischen vollständigen und unvollstädigen Laesionen. Die häufigsten anfänglichen Kundgebumgen bei 25 Patienten waren Schmerzen, bei 8 Patienten sensorische Verluste und bei 2 Patienten Schwäche der Motorik. Bei 25 Patienten war der Befall bilateral, bei 12 Patienten war der Trigeminus-Bezirk einbezogen. 3 patienten entwickelten Hirmstammbeteiligung.

Die naturliche Geschichte des Zusandes wird diskutiert.

\section{REFERENCES}

Barnett, H. J. M., Bottrell, E. H., Jousse, A. T. \& Wynne Jones, M. (I966). Progressive myelopathy as a sequel to traumatic paraplegia. Brain., 89, I59-I47.

Barnett, H. J. M., Foster, J. B. \& Hudgson, P. (I973). 'Syringomyelia' Volume I. Major problems in Neurology, W. B. Saunders Co Ltd. 
BASTIAN, H. C. (I 867). On a case of concussion-lesion with extensive secondary degeneration of the spinal cord. Proceedings of the Royal Medical and Churirgical Society of London, 50, 499.

Dejerine, J. J. (I9I4). Semiologie des Affections du Systeme Nerveux. Paris: Masson.

Finckle, J. R. (I960). Lesions ascending from spinal cord injuries. Proc. Ninth Ann. Clinic. Sp. Cord Injuries Conf., pp. 45-48.

FreEMAN, L. W. (I950). Ascending spinal paralysis. F. Neurosurg., 16, I 20-122.

GARDNER, W. J. (I973). Hydrodynamic mechanism of syringomyelia: its relation to myelocele. Fournal of Neurology, Neurosurgery and Psychiatry, 28, 247-259.

GuttmanN, SiR Ludwig (1973). Spinal Cord Injuries; Comprehensive Management and Research. Oxford, Blackwell.

Holmes, G. (1915). The Goulstonian Lecture on Spinal Injuries of Warfare. British Medical fournal, I915, 2, 769-774.

Morvan, A. M. (I883). De la paresie analgesique a panaris des extremities superieures ou pareso-analgesie des extremeties superieures. Gazette Hebdomadaire Medicine et de Chirurgie, 35, 580.

RAvichandRAN, G. \& Silver, J. R. (I982). Survival following traumatic tetraplegia. Accepted for publication, Paraplegia.

Shannon, N., Symon, L., Logue, V., Cull, D., Kang, J. \& Kentall, B. (I98I). Clinical features, investigations and treatment of post traumatic syringomyelia. Fournal of Neurology, Neurosurgery and Psychiatry, Vol. 44, No. I, p. 35-42.

Strumpell, A. (1880). Beitrage Zur Pathologie Des Ruckenmarks. Archives Fur Psychiatrie Und Nervenkrankheiten, 10, 676.

Williams, B. (I979). Orthopaedic features in the presentation of syringomyelia. Fournal of Bone and foint Surgery, Vol. 6I-B, No. 3, August 1979. 314-323. 